Preliminary communication

\title{
TEXTURE-MODIFYING PROPERTIES OF MICROBIAL TRANSGLUTAMINASE ON 2 POPULAR HUNGARIAN PRODUCTS: TRAPPIST CHEESE AND FRANKFURTER
}

\author{
L. Darnay*, A. Tóth, B. Salamon, K. PapiK, G. Oros, G. JónÁs, K. Horti, \\ K. KONCZ and L. FrIEDRICH \\ Department of Refrigeration and Livestock Products Technology, Faculty of Food Science, \\ Szent István University, H-1118 Budapest, Ménesi út 43-45. Hungary
}

(Received: 1 June 2016; accepted: 19 August 2016)

The aim of this study was to show how microbial transglutaminase (mTG) can be used as an effective texture-
modifier for two popular Hungarian products: Trappist cheese and frankfurter. In both cases we investigated how
components of these products, milkfat in cheese and phosphate in frankfurter, can be substituted by mTG. Therefore,
Trappist cheese samples were produced from cow milk of $2.8 \%, 3.5 \%$, and $5 \%$ milk fat. The effect of ripening was
evaluated with Texture Profile Analysis (TPA) and sensory evaluation (scoring test, 10 trained panellists). Springiness
and cohesiveness values were significantly higher by enzyme-treated semi-hard cheese samples at lower milk fat
levels. Sensory evaluation showed that the enzyme-treatment led to higher scores by cheese samples made from cow
milk of $3.5 \%$ and $5 \%$ milk fat. Frankfurter was made with $0.1 \%, 0.3 \%, 0.5 \%$, and $0.7 \%$ tetrasodium pyrophosphate,
and partly enzyme-treated with $0.2 \%$ commercial mTG enzyme preparation. Our results showed that mTG is able to
significantly improve hardness and crunchiness by frankfurters made with $0.1 \%$ phosphate addition. Our sensory
evaluation suggests that mTG and phosphate should be applied in combination in order to have a final product with
recognisably more homogeneous texture.
Keywords: milk fat, ripening, Trappist cheese, low-phosphate, frankfurter, microbial transglutaminase,
texture, sensory analysis texture, sensory analysis

Microbial transglutaminase (mTG, protein-glutamin $\gamma$-glutamyltransferase, E.C. 2.3.2.13) is widely used, mainly for dairy and meat products (MотоKI \& KUMAZAwA, 2000; KieliszeK \& Misiewicz, 2014), but recently also in order to develop innovative packaging (PoRTA et al., 2016). Phosphate influences the hardness and chewability, therefore the consumer acceptance of emulsified sausages, as it increases muscle protein extraction, which leads to stronger gel matrix (CANDOGAN \& KolSARICI, 2003). However, water-holding of phosphate is found to be limited at $0.4 \%$ concentration in emulsified sausages (LÜ \& ZHANG, 2000; WANG et al., 2009). The most widespread functional phosphates are diphosphates (example: tetrasodium pyrophosphate, TSPP), as they act on actomyosin complex of meat protein at once and have high pH value (NGUYEN et al., 2011). Moreover, phosphates slow the growth of some Grampositive bacteria (FEINER, 2006; BuŇKOVÁ et al., 2008). Recently there is great attention focused on the reduction of salt and phosphate by meat products (AlLAIs, 2010), which can be achieved by the crosslinking of protein molecules with mTG. Due to the intra- and inter-

* To whom correspondence should be addressed.

Phone: +36 30753 7077; e-mail: darnay.livia@gmail.com

0139-3006/\$20.00 C 2017 Akadémiai Kiadó, Budapest 
molecular covalent bonds catalysed by $\mathrm{mTG}$, the formed myofibrillar protein polymers can restore the texture of pale soft exudative (PSE) pork meat (MiLkowski et al., 1999). Our aim was to analyse the simultaneous effect of $0.1-0.7 \%$ TSPP and $0.2 \%$ mTG. Furthermore, we studied how phosphate could be replaced by mTG to produce a low-phosphate frankfurter with adequate texture. Texture has a key importance not just by the final cheese product but also in order to follow the ripening state of semi-hard cheese. It was mainly followed by imaging of the development of eye-growth (Huc et al., 2014a; SoODAm et al., 2014). This technique has even more promising results if it is coupled with $\mathrm{CO}_{2}$ release measurements (Huc et al., 2014b). However, the most widespread technique for that is the Texture Profile Analysis (TPA). To our best knowledge, microbial transglutaminase (mTG, protein-glutamin $\gamma$-glutamyltransferase, E.C. 2.3.2.13), affecting texture properties such as hardness of semihard cheese, was only analysed at selected ripening states: after 1 week (Cozzolino et al., 2003), 4 weeks (Di Pierro et al., 2010; Aaltonen et al., 2014), and 24 weeks (Aaltonen et al., 2014), but was not monitored during the whole ripening period. Therefore, our main objective was to follow changes of hardness due to mTG during 4-10 weeks of ripening. Aims were extended with investigation on how the fat level influences the texture modifying properties of mTG.

\section{Materials and methods}

\subsection{Manufacturing and ripening process of semi-hard cheese}

Semi-hard cheese samples were made from $2.8 \%$ fat pasteurized cows' milk, and $30 \%$ fat whipping cream (Fuchs Tej Ltd., Valkó, Hungary) was used to set the milk fat level to 2.8\%, $3.5 \%$, and $5 \%$ fat. The milk was then heated up to $30{ }^{\circ} \mathrm{C}$ in a 101 Armfield FT-20A type cheese-vat (Bridge House, Great Britain), and 0.025\% (w/v) $\mathrm{CaCl}_{2}$ (Sigma Aldrich Ltd., Budapest, Hungary) was added. A stirrer (14 r.p.m.) was used for proper mixing during the whole process, except during curdling. In case of enzyme treated samples, $0.01 \%(\mathrm{w} / \mathrm{v}) \mathrm{mTG}$ (Probind $\mathrm{CH}$, nominal activity: $58 \mathrm{U} \mathrm{g}^{-1}$, BDF Natural Ingredients, Girona, Spain) was applied. A freeze-dried concentrated lactic starter culture consisting of Lactococcus lactis subsp. lactis, Lactococcus lactis subsp. cremoris, Lactococcus lactis subsp. lactis biovar. diacetylactis, and Streptococcus thermophilus was used as cheese culture (MA 4001, LYO 5DCU, Danisco, Epernon, France). After $15 \mathrm{~min}$ incubation, 0.05\% (v/v) chymosin (Présure Simple Brun, Danisco, Melle, France) was added. Stirring was stopped 5 min after chymosin was added. After cutting, curd was heated until $39^{\circ} \mathrm{C}$ to help whey separation. As a last step of curdling, whey was separated. The curd was pressed for $24 \mathrm{~h}$ with a force of $20 \mathrm{~kg}$ per $\mathrm{kg}$ cheese and then cured in $20 \%(\mathrm{w} / \mathrm{v}) \mathrm{NaCl}$ solution for one day. The desiccation lasted 1 day, after which cheese was put in Flexo-vacuum PS650 five-layers vacuum package (oxygen permeability: $100 \mathrm{~cm}^{3} \mathrm{~m}^{-2} 24 \mathrm{~h}^{-1}$, steam permeability: $6 \mathrm{~g} \mathrm{~m}^{-2} 24 \mathrm{~h}^{-1}$ ) and ripened at $13{ }^{\circ} \mathrm{C}$ for 10 weeks.

\subsection{Manufacturing of frankfurters}

Pork meat batter was prepared as follows: half portion $(235 \mathrm{~g})$ of minced pork meat $(80 \%$ purity) was ground first with half portion ( $180 \mathrm{~g})$ of ice cubes, then additives and seasonings were added in four 1-minute-long steps (step 1: $0.1-0.7 \%$ Na soluprate (TTSP, Solvent Inc., Hungary), step 2: $1.8 \%$ salt (nitrite curing salt containing $0.4-0.5 \% \mathrm{NaNO}_{2}$, Salinen Austria 
AG., Austria), step 3: remaining half portion of minced pork meat, step 4: 1.25\% ground dried paprika (Kalocsai Füszerpaprika Ltd., Hungary), 1.2\% ground white pepper (importer: R-Coop 3 Inc., made in Indonesia), $160 \mathrm{~g}$ of pork backfat (5 mm particle size), step 5: 0.2\% mTG (Probind TX, nominal activity: $85-120 \mathrm{U} \mathrm{g}^{-1}$, BDF Natural Ingredients, Girona, Spain)). The meat batters were partly analysed (for surface colour, extrusion, adhesiveness) partly stuffed into $21 \mathrm{~mm}$ diameter cellulose casings (Kalle Hungária Ltd., Hungary) and handlinked. Frankfurters were pre-dried $\left(60^{\circ} \mathrm{C}, 15 \mathrm{~min}\right)$, cooked (until $72{ }^{\circ} \mathrm{C}$ core temperature), and cooled in shower (until $10^{\circ} \mathrm{C}$ core temperature) in CS350 EL type smoking machine (Korax Ltd., Hungary). After drainage, frankfurters were cooled to $5{ }^{\circ} \mathrm{C}$ and stored in vacuum-package at the same temperature for further investigations. Commercial frankfurter with $47 \%$ pork meat content and $0.5 \%$ phosphate concentration was also analysed for comparison.

\subsection{Texture Analysis}

1.3.1. Springiness and cohesiveness of Trappist cheese. The samples were measured after 4 , 6,8 , and 10 weeks of ripening. Each cheese was cut into halves and cylinders of $12 \mathrm{~mm}$ height were taken from the centre towards the rind with a core sampler $12 \mathrm{~mm}$ in diameter. The prepared cheese core samples were tempered at $12{ }^{\circ} \mathrm{C}$ before TPA analysis. TPA analysis was performed with TA.XTPlus (Stable Micro Systems, Godalming, UK) Texture Analyser used with a $500 \mathrm{~N}$ load cell. The samples were axially compressed two times to $70 \%$ of their original height with $35 \mathrm{~mm}$ cylinder probe at a crosshead speed of $2 \mathrm{~mm} \mathrm{~s}^{-1}$. Force-time deformation curves were evaluated with Texture Exponent 32 as the given software of TA.XTPlus, and the hardness parameter was selected for analysis. Measurements were done in 10 parallels.

1.3.2. Extrusion and adhesiveness by pork meat batter. Extrusion and adhesiveness was measured with the conical measuring head of TA.XTPlus (Stable Micro Systems, Great Britain). The cross-head pushed the $90^{\circ}$ cone probe of spreadability rig with $2 \mathrm{~mm} \mathrm{sec}{ }^{-1}$ speed into the sampling holder. The meat batter samples were tempered to $12{ }^{\circ} \mathrm{C}$ and the measuring time was $90 \mathrm{sec}$. Three replicates of each sample were evaluated using the official software of the instrument called Texture Exponent 32.

1.3.3. Hardness and crunchiness by frankfurters. Hardness was also measured with TA.XTPlus (Stable Micro Systems, Great Britain). Ten frankfurter cores (diam. $=12 \mathrm{~mm}$, height $=12 \mathrm{~mm}$ ) were axially compressed two times to $70 \%$ of their original height. with 35 $\mathrm{mm}$ cylinder probe. Force-time deformation curves were derived from a $500 \mathrm{~N}$ load cell applied at a crosshead speed of $2 \mathrm{~mm} \mathrm{~s}^{-1}$. The samples were tempered to $12{ }^{\circ} \mathrm{C}$ and the measuring time was $2 \mathrm{~min}$. Crunchiness was measured with $2 \mathrm{~mm}$ cylinder probe with the above mentioned crosshead speed till $25 \mathrm{~mm}$ penetration. Frankfurters were cooked $1 \mathrm{~min}$ in boiling water just before measurement. Samples were fixed to the base with sample holder and $5 \mathrm{~cm}$ surface was analysed through casing. The averages are results of at least 3 replicates.

\subsection{Sensory analysis}

(i) Trappist cheese: Sensory evaluation with 20 points Scoring Test was applied to evaluate the samples according to their appearance (3), inner colour (3), odour (3), taste (5), texture 
(3), and cheese eyes (3) using a comprehensive vocabulary of these descriptors (Hungarian STANDARD, 1988). Sensory sessions were organised for at least 10 trained panellists.

(ii) Frankfurter: After storage overnight, the samples were evaluated with a trained panel (10 members) with difference test focusing on texture. Texture attributes as homogeneity of cut surface, springiness, and porosity were ranked on a $-5-0-5$ score scale compared to reference sample, which was anchored at the exact middle of the scale ( 0 point $)$.

\subsection{Statistical analysis}

Shapiro-Wilk test was applied to evaluate the normality of our research data.

\section{Results and discussion}

\subsection{Texture Analysis}

(i) Trappist cheese: The effect of enzyme treatment and fat content of cheese milk was also analysed during ripening with the help of TPA method ( $70 \%$ compression) focusing on the springiness (Fig. 1) and cohesiveness of cheese. According to our research results, mTG significantly affected the springiness at lower fat levels $(2.8 \%$ and $3.5 \%)$ independently of ripening time. The cohesiveness represents the inner binding force of the studied material. During ripening, cheese tends to soften and crumble. The enhanced cohesiveness of samples suggests that the cross-binding effect of mTG leads to structure stabilization at $2.8 \%$ and $3.5 \%$ fat levels (data not shown).

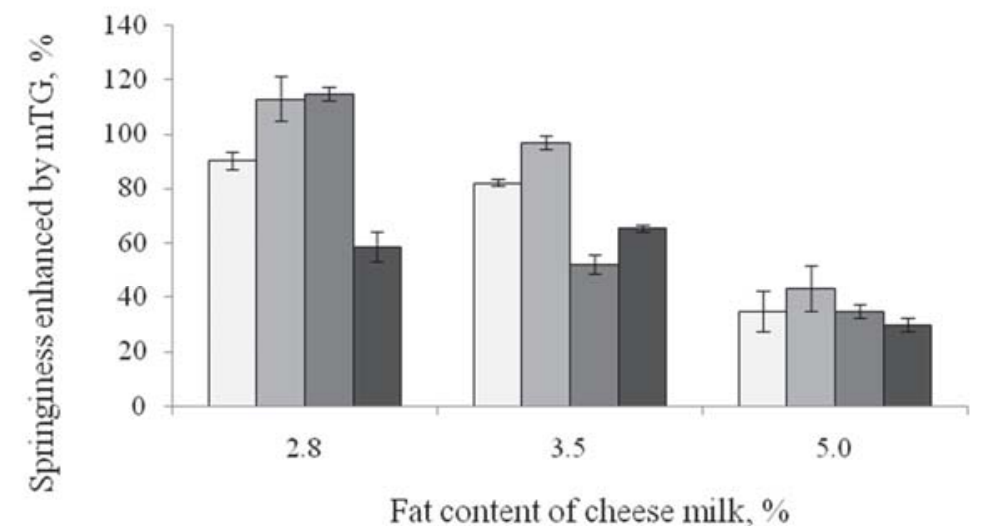

Fig. 1. Effect of fat content of cheese milk on the springiness development caused by mTG : 4 weeks; ㅍ: 6 weeks; ㅁ: 8 weeks; : 10 weeks

(ii) Meat batter: The extrusion force shows how easy the stuffing of the meat batter is. The texture of meat batters made with industrially applied phosphate addition $(0.3 \%)$ could not be enhanced by mTG (Table 1). 
Table 1. Technofunctional properties of pork meat batters depending on phosphate level

\begin{tabular}{ccc}
\hline $\begin{array}{c}\text { Phosphate level } \\
(\%)\end{array}$ & $\begin{array}{c}\text { Extrusion enhanced by mTG } \\
(\%)\end{array}$ & $\begin{array}{c}\text { Adhesiveness enhanced by mTG } \\
(\%)\end{array}$ \\
\hline 0.1 & -2 & 2 \\
0.3 & 1 & 1 \\
0.5 & 79 & 88 \\
0.7 & 20 & 25 \\
\hline
\end{tabular}

(iii) Frankfurter: The mTG enzyme led to more hardness (11-16\%) independently of actual phosphate concentration of the samples (Table 2). We suggest the enzyme-treatment by $0.1-0.3 \%$ phosphate addition as $\mathrm{mTG}$ had in that interval the most significant effect on springiness and crunchiness of frankfurters. The enzyme treated $0.1 \%$ phosphate frankfurter had $-3 \%$ hardness, $15 \%$ more springiness, and $8 \%$ more crunchiness compared to commercial frankfurter with $0.5 \%$ phosphate level (data not shown).

Table 2. Technofunctional properties of frankfurters depending on phosphate level

\begin{tabular}{cccc}
\hline $\begin{array}{c}\text { Phosphate level } \\
(\%)\end{array}$ & $\begin{array}{c}\text { Hardness } \\
\text { enhanced by mTG } \\
(\%)\end{array}$ & $\begin{array}{c}\text { Springiness } \\
\text { enhanced by mTG } \\
(\%)\end{array}$ & $\begin{array}{c}\text { Crunchiness } \\
\text { enhanced by mTG } \\
(\%)\end{array}$ \\
\hline 0.1 & 13 & 4 & 19 \\
0.3 & 11 & 2 & 69 \\
0.5 & 16 & 7 & 42 \\
0.7 & 16 & 11 & 16 \\
Commercial $(0.5)$ & 23 & 11 & 37 \\
\hline
\end{tabular}

\subsection{Sensory analysis}

(i) Trappist cheese: Our evaluation showed that $2.8 \%$ fat is not sufficient for $\mathrm{mTG}$ to enhance textural properties, which probably influenced the panellists in the overall judging (Fig. 2). We assume that $3.5 \%$ fat content is needed for $\mathrm{mTG}$ to enhance odour, taste, and cheese-eyes development. However, the enzyme-treatment could even improve the inner colour and taste of the semi-hard cheese samples when manufactured from 5\% cows' milk.

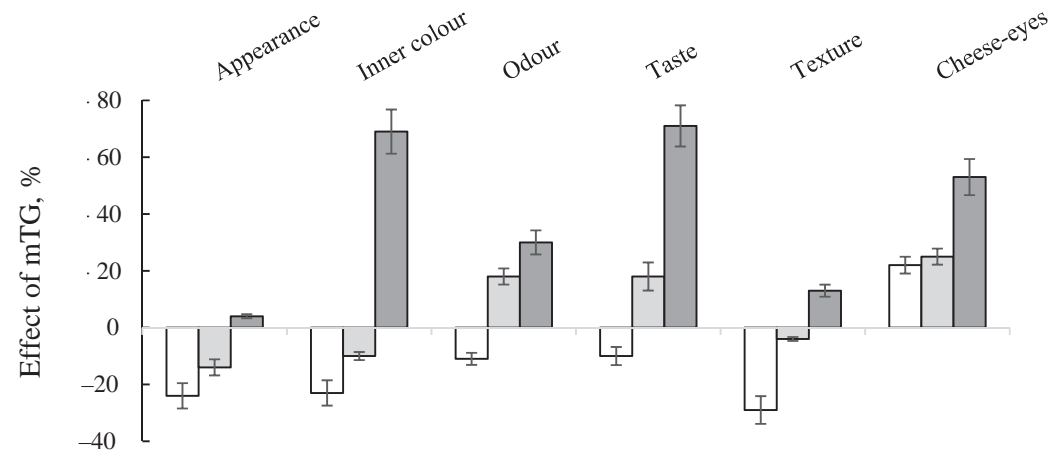

Fig. 2. Changes of sensorial attributes depending on fat content of cheese milk ㅁ: $2.8 \%$ cheese milk; $\varpi: 3.5 \%$ cheese milk; $\square: 5 \%$ cheese milk; 
(ii) Frankfurter: The effect of enzyme treatment compared to the control at the different phosphate levels is shown in Figure 3. Porosity refers to the recognised air bubbles in the cooked meat batter. This could be eliminated with the help of mTG if at least $0.3 \%$ phosphate was added. Springiness was observed by touching the frankfurter cores between two fingers. The mTG could enhance springiness independently of phosphate levels. Among texture properties homogeneity was also enhanced by $\mathrm{mTG}$, however the differences were noted rather at lower $(0.1-0.3 \%)$ phosphate levels.

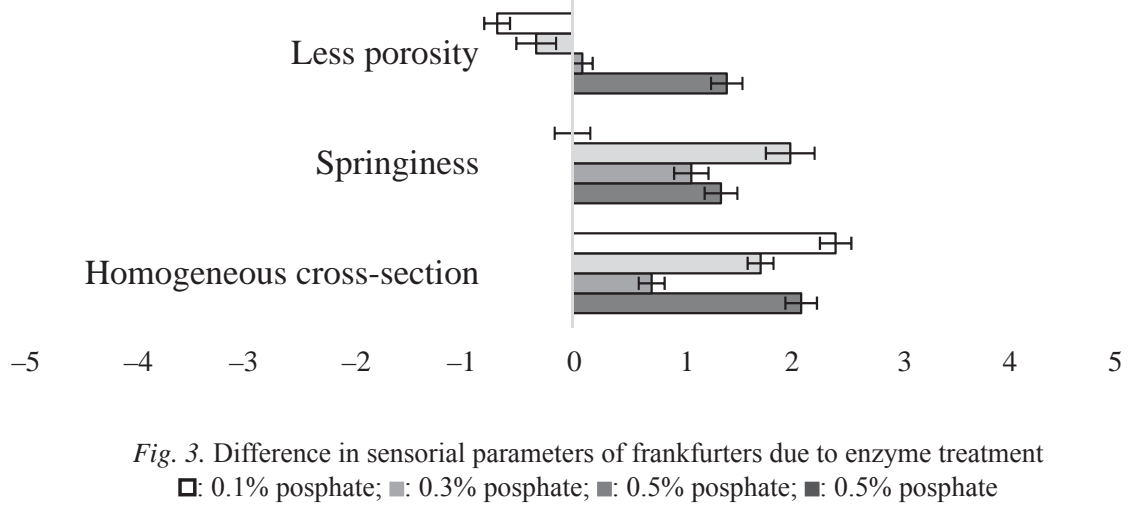

\subsection{Statistical analysis}

According to Shapiro-Wilk test, both cheese $\left(\mathrm{W}_{\min }=0.877, \mathrm{p}_{\min }=0.256\right)$ and frankfurter $\left(\mathrm{W}_{\min }=0.849, \mathrm{p}_{\min }=0.120\right)$ measurement resulted in normal distribution.

\section{Conclusions}

The results proved that mTG is able to modify the texture of Trappist cheese and frankfurter in a way that is also acceptable for the consumers. In case of Trappist cheese, this study proved that the cross-binding effect of mTG leads to higher cheese yield independently of milk fat level, which is due to whey incorporation. The enzyme-treated cheese samples have lower fat levels, but have higher springiness and cohesiveness throughout the 4-10 weeks ripening time. Sensory analysis revealed that the enzyme-treatment improved nearly all sensory attributes if semi-hard cheese was produced from $3.5 \%$ or $5 \%$ cows' milk. If we consider frankfurter, it is important to highlight that $0.2 \% \mathrm{mTG}$ may increase the water holding capacity with $20 \%$ by low-phosphate $(0.1-0.3 \%)$ frankfurters and it also contributes to more homogeneous cut surface. According to our comparison with commercial product, low-phosphate $(0.1 \%)$ enzyme-treated frankfurters have adequate hardness and improved springiness and crunchiness, which is a promising sign for product development in the future.

We take this opportunity to express our profound gratitude for Márta Csukáné-Nemes for her technical support. We thank for BDF Natural Ingredients to provide the commercial mTG preparation used for this study. 


\section{References}

Aaltonen, T., Huumonen, A. \& Myllärinen, P. (2014): Controlled transglutaminase treatment in Edam cheesemaking. Int. Dairy J., 38, 179-182.

Allais, I. (2010): Emulsification. -in: ToldRÁ, F. (Ed.) Handbook of meat processing. Wiley-Blackwell, Iowa. pp. 143-168.

BuñKová, L., Pleva, P., BuñKa, F., Valášek, P. \& Kráčmar, S. (2008): Antibacterial effects of commercially available phosphates on selected microorganisms. Acta Univ. Agric. Silvic. Mendel. Brun., 56, 19-24.

Candogan, K. \& Kolsarici, N. (2003): Storage stability of low-fat beef frankfurters formulated with carrageenan or carrageenan with pectin. Meat Sci., 64, 207-214.

Cozzolino, A., Di Pierro, P., Mariniello, L., Sorrentino, A., Masi, P. \& Porta, R. (2003): Incorporation of whey proteins into cheese curd by using transglutaminase. Biotechnol. Appl. Bioc., 38, 289-295.

Di Pierro, P., Mariniello, L., Sorrentino, A., Valeria, C., Glosafatto, L., Chianese L. \& Porta, R. (2010): Transglutaminase-induced chemical properties of cheese. Food Biotechnol., 24, 107-120.

FeIner, G. (2006): Meat products handbook, Practical science and technology. Woodhead Publishing Ltd, Cambridge. 672 pages.

Huc, D., Challois, S., Monziols, M., Michon, C. \& Mariette F. (2014a): Spatial characterisation of eye-growing kinetics in semi-hard cheeses with propionic acid fermentation. Int. Dairy J., 39, 259-269.

Huc, D., Roland, N., Grenier D., Challois, S., Michon, C. \& Mariette, F. (2014b): Influence of salt content on eye growth in semi-hard cheeses studied using magnetic resonance imaging and $\mathrm{CO}_{2}$ production measurements. Int. Dairy J., 35, 157-165.

Hungarian Standard (1988): Trappista sajt (Trappist cheese). MSZ 12280-87

Kieliszer, M. \& Misiewicz, A. (2014): Microbial transglutaminase and its application in the food industry. A review. Folia microbiol., 59, 241-250

Lü, B. \& Zhang, J. (2000): Studies on the water holding capacity of meat products. Food Sci., 21, $23-27$.

Мотокi, M. \& Kumazawa, Y. (2000): Resent research trends in transglutaminase technology for food processing. Food Sci. Technol. Res., 6, 150-160.

Milkowski, A.I., Madison, W. \& Sosnicki, A.A. (1999): Method for treating PSE meat with transglutaminase. United States Patent 5,928,689

NGuYen, H.B.S.L., GÁL, R. \& BuŇKA, F. (2011): Use of phosphates in meat products. Afr. J. Biotechnol., 10, 1987419882.

Porta, R., Di Pierro, P., Sabbah, M., Regalado-Gonzales, C., Mariniello, L., Kadivar, M. \& Arabestani, A (2016): Blend films of pectin and bitter vetch (Vicia ervilia) proteins: Properties and effect of transglutaminase. Innov. Food Sci. Emerg., 36, 245-251.

Soodam, K., Ong, L., Powell, I.B., Kentish, S.E. \& Gras, S.L. (2014): The effect of milk protein concentration on the microstructure and textural properties of full fat cheddar cheese during ripening. Food Bioprocess Tech., 7, 2912-2922.

WANG, P., Xu, X. \& Zноu, G. (2009): Effects of meat and phosphate level on water-holding capacity and texture of emulsion-type sausage during storage. Agric. Sci. China, 8, 1475-1481. 